\title{
Mdj1p, a Novel Chaperone of the DnaJ Family, Is Involved in Mitochondrial Biogenesis and Protein Folding
}

\author{
Neil Rowley," Carina Prip-Buus, $\dagger$ \\ Benedlkt Westermann, + Carol Brown," \\ Elisabeth Schwarz, † Bart Barrell," \\ and Walter Neupert ${ }^{\dagger}$ \\ "Medical Research Council \\ Hills Road \\ Cambridge $\mathrm{CB} 2 \mathrm{2QH}$ \\ England \\ †Institut für Physiologische Chemie \\ Goethestrasse 33 \\ 80336 München \\ Federal Republic of Germany
}

\section{Summary}

Mdj1p, a novel member of the DnaJ family, is a heat shock protein that is associated with the inner membrane of mitochondrla of Saccharomyces cerevislae. Disruption of the MDJ1 gene resulted in a petite phenotype, loss of mitochondrial DNA, and inviability at $37^{\circ} \mathrm{C}$. Import of precursor proteins was not affected by a lack of Mdj1p, but folding of newly imported proteins was markedly impaired. The efficiency of refolding of a tester protein, dihydrofolate reductase, was significantly reduced in mitochondria lacking Mdj1p after incubation at elevated temperature. We conclude that Mdj1p is an important mitochondrial chaperone that participates in the folding of newly imported proteins and in the protection of proteins against heat denaturation and aggregation.

\section{Introduction}

Heat shock proteins of the Hsp70 and Hsp60 family have been shown to play essential roles as molecular chaperones in the translocation of proteins into mitochondria and in the subsequent folding and assembly of the newly imported precursor proteins within the organelle (Cheng et al., 1989; Ostermann et al., 1989; Scherer et al., 1990; Kang et al., 1990; Manning-Krieg et al., 1991; Craig et al., 1993; Ellis, 1993; Neupert and Pfanner, 1993). Cytosolic members of the Hsp70 class are required to maintain proteins in a transport-competent conformation during translocation across membranes (Chirico et al., 1988; Deshaies et al., 1988). One member of the family, Ssc1p, is located in the mitochondrial matrix and mediates the vectorial transfer of precursor proteins across the two mitochondrial membranes (Kang et al., 1990). The partially unfolded polypeptide chain, bound to Ssctp, is then thought to be passed on to the chaperonin Hsp60, which facilitates protein folding and assembly (Cheng et al., 1989; ManningKrieg et al., 1991; Martin et al., 1992).

Although considerable evidence has been accumulated in favor of these roles for Hsp70 and Hsp60, it remains unclear whether additional components are required in these complex processes. In fact, it seems likely that in mitochondria as in prokaryotic organisms, additional components may be necessary for the efficient regulation of heat shock protein activity. In Escherichia coli, the single Hsp70, DnaK, has been shown to be functionally active in a dynamic complex with two other heat shock proteins, DnaJ and GrpE. DnaJ stimulates the ATPase activity of DnaK, whereas GrpE acts as a nucleotide exchange factor (Liberek et al., 1991). In this manner, these three heat shock proteins participate in a variety of processes, such as bacteriophage $\lambda$ DNA replication, protein folding, and regulation of heat shock response (Zylicz et al., 1989; Langer et al., 1992; Gamer et al., 1992).

In the yeast Saccharomyces cerevisiae, several genes of Dnad homologs have so far been characterized: SEC63, SCJ1, YDJ1, SIS1, ZUO1, and XDJ1 (Rothblatt et al., 1989; Sadler et al., 1989; Blumberg and Silver, 1991; Caplan and Douglas, 1991; Atencio and Yaffe, 1992; Luke et al., 1991; Zhang et al., 1992; Schwarz et al., in press). Among these, Sec63p and Ydj1p have been shown to be involved in protein translocation across intracellular membranes (Rothblatt et al., 1989; Caplan et al., 1992). SCJ1 was identified as a gene whose overexpression restores the proper targeting of a fusion protein containing a nuclear localization sequence preceding the cytochrome $\mathrm{cl}$ coding sequence to the mitochondria (Blumberg and Silver, 1991). Scj1p has been suggested to be localized within the mitochondria; however, its function and subcellular localization have yet to be demonstrated. Recent evidence suggests that Sis $1 p$ facilitates the formation of a specific protein complex within the translation machinery (Zhong and Arndt, 1993).

From what is known about the concerted action of heat shock proteins, especially in the prokaryotic system, one might predict that mitochondria have conserved the protein folding apparatus of their endosymbiontic ancestors. Thus, the functional characterization of a mitochondrial DnaJ homolog in protein import and folding reactions should provide insight into the complex processes that contribute finally to organelle biogenesis. Here, we report a DnaJ homolog, Mdj1p, which is located in the mitochondrial matrix and is essential for respiration-dependent growth. Furthermore, our results demonstrate a role for Mdj1p in the folding of imported precursor proteins and the prevention of protein aggregate formation.

Results

Nucleotide and Predicted Amino Acid Sequence of MDJ1

The mitochondrial DnaJ (MDJ1) gene was identified during the DNA sequencing of a $S$. cerevisiae genomic library (a gift of M. V. Oison; Olson et al., 1986; Riles et al., 1993). MDJ1 lies head to head with HSP12/GLP1, and between the SUF9 and CDC4 genes, on chromosome VI. The 2457 bp sequence of the MDJ1 nucleotide sense strand and predicted protein sequence are shown in Figure 1. MDJ1 is a single copy gene, as demonstrated by hybridization 


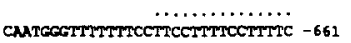
C........

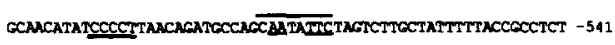

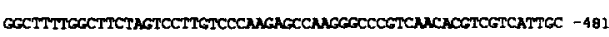
TACCGOCAGCTEGCACCCACACATCACCCACCCITTTTTTTCCATTTTCGOCT

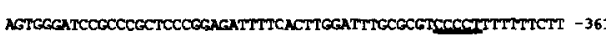
CATTCTCTGACTCECCCAACCTTCTCCCACTTTTCTGTGTATCAACAOCAMUAGACGAG -301 ANAACEAGNACTCCGAANAATACCGAACANGACGGTAACAGMATGTGCATTTGGATGAGC -241 GGGTAACAGATEGAAGTACCORCCAAMGAGGGTAATATETTCTGCTYTTTTTTATCAT -181

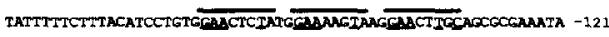

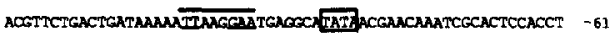

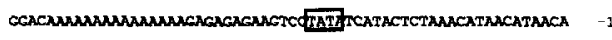

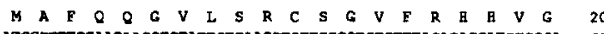
ATGGETTTCCAACAASCTGTATTGTCAACETGTTCCOCTGTCTTTAGACACCATETECGA

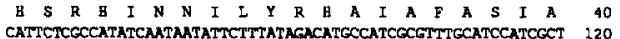

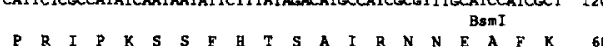

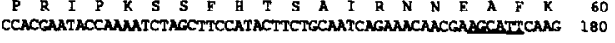

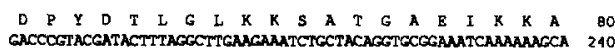
$\begin{array}{llllllllllllllllllllll}\text { Y } & Y & K & \text { I } & \text { A } & K & K & Y & \text { A } & \text { P } & D & I & N & K & E & P & D & A & E & K & 100\end{array}$ TACTACAMACTGECAAAGANGTHCCACCOGGATATCAACAAGGAACCGGATGCTGAGAMG 300 K F I D L Q N A Y E I I S S D E T K R O $Q$ AAATTCCACGATTTACAGANCOCTLATGAAATTCTGTCACACGAMACGAKAACSCAGCAC 360

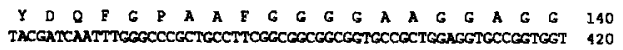

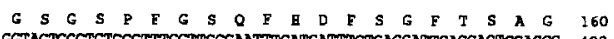
GCTAGTCCCTCTCCCTTTGCT TCCCANTTTCATCATTTCTCAGGATTCACCAGTECAGEC 480 $G$ S

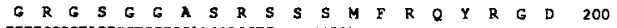
GCCCCOOCTAOCGGTGGCGCANGCACGTCGTCATCTATGTTCAGACMATATACSGGCGAC 600

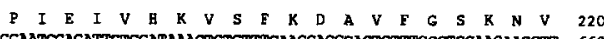

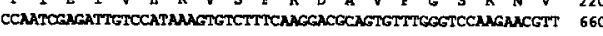
$\begin{array}{lllllllllllllllllllll}\text { Q } & L & R & E & S & A & L & D & P & C & S & T & C & S & G & \text { I } & G & \text { M } & K & P & 240\end{array}$

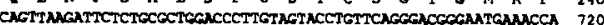
N T A K V V S S C S S T C C A C C T G

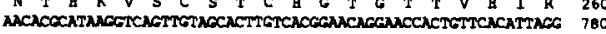

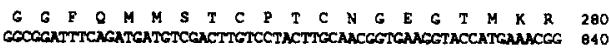
P O D N E T X C E G E G V O V N R A K T 300

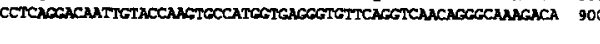
$\begin{array}{lllllllllllllllllllll}I & T & V & D & \text { L } & P & \text { A } & G & \text { L } & Q & D & G & D & V & V & R & I & P & G & Q & 320\end{array}$ ATTACOETGEACTTECCACAMEGATTACAGGACGCCGACGTCETCAEGATCCCTGGCCAA 960

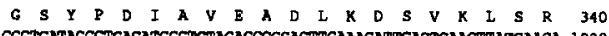
GCCTCATACCCT GACATCCCTETAGACECCGACTTGAAGATTCAGTCMGTTATCANGA 1020

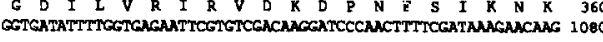
$\begin{array}{lllllllllllllllllllll}\text { Y } & D & I & N & Y & D & X & E & \text { I } & P & \text { I } & T & \text { I } & \text { A } & \text { A } & \text { I } & G & G & \text { T } & \text { V } & 380\end{array}$ TACGATATTTOCTACGACANCANGATTCCTATAACCACAGCTECACTTGGTGETACTGTC 1140 T I P T V E G Q K I R I K V A P $G$ T O Y 400 $N$ O V I S I P N M G V P K $T$ T $S$ I I I I $G$ C 420 AATCALGTGATATCCATTCCTACATCEGTGTTCCTAHACATCAACCATTCCCCGTGAT 1260

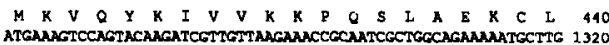
W E A I A D V I N N D D M A K K I M O P G 460 TESGACOCACTEGCACATGTCACCANCGATGACATESCCNAAMAACCATCCAACCGCGC 1380 $\begin{array}{llllllllllllllllllll}\text { I A A A G I A I N E } & E & I & I & K & K & O & K & O & E & E & E & 400\end{array}$

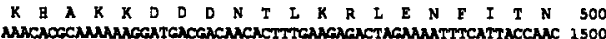
T $F$ R K I K $\in$ D K K N

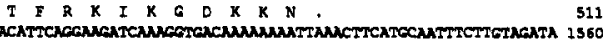

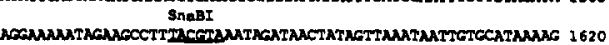

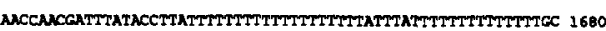

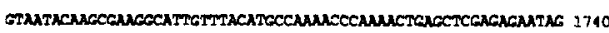

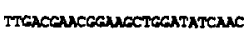

of a 1998 bp probe containing the complete MDJ1 coding sequences on a Southern blot (data not shown). Upstream of the MDJ1 open reading frame, at positions -28 and -86 with respect to the translational start codon, are two potential TATA boxes. Furthermore, the MDJ1 open reading frame is preceded by several weak matches to the heat shock element nGAAnnTTCn (Amin et al., 1988; Young and Craig, 1993) and five copies of the CCCCT motif reported to be involved in heat shock factor-independent gene induction (Kobayashi and McEntee, 1993) (Figure 1). The heat inducibility of MDJ1 was tested by Northern blot analysis, which revealed a 2- to 3-fold transient increase of transcript abundance upon shift of the cells from $24^{\circ} \mathrm{C}$ to $37^{\circ} \mathrm{C}$ (data not shown).

The predicted amino acid sequence of Mdj1p consists of 511 residues with $33 \%$ identity to the $E$. coli DnaJ gene product. An alignment of these sequences with the other reported yeast DnaJ-like polypeptide sequences is presented in Figure 2. Highest similarity between Mdj1p and these other proteins is found in a 68 amino acid stretch (residues 59-127), conserved in all members of the DnaJ protein family, that is termed the $\mathrm{J}$ region (reviewed by Caplan et al., 1993; Silver and Way, 1993). In common with most other members of this protein family, Mdj1p possesses a glycine-rich stretch in the central portion of

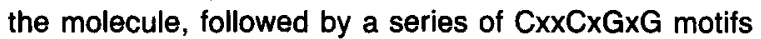
that are organized into four repeats (Figure 2).

\section{MDJ1 Is Essential for the Formation of Respiratory-Competent Mitochondria}

To investigate whether MDJ1 is an essential gene, the Bsml-SnaBI fragment (bases 173-1581, see Figure 1) of the cloned gene was replaced with a URA3 encoding fragment and was transformed into the diploid strain $a / \alpha 735$. The presence of a disrupted and a wild-type copy of the gene was confirmed by polymerase chain reaction (PCR) and Southern blot analysis (data not shown). The heterozygous diploid (a/aYNR3) was sporulated, and 39 tetrads were dissected. All of the tetrads showed a uniform 2:2 segregation into small and large colonies at a growth temperature of $30^{\circ} \mathrm{C}$ (Figure $3 \mathrm{~A}$ ). The small colonies were all Ura ${ }^{+}$, indicating that the moj1 disruption cosegregated with the slow growth phenotype. Further replica-plate analysis showed that the Ura ${ }^{+}$spores were inviable at $37^{\circ} \mathrm{C}$ on all carbon sources tested. They failed to grow on glycerol, a nonfermentable carbon source, at $24^{\circ} \mathrm{C}$ (Figure 3B), exhibiting a petite phenotype. The temperature-sensitive

Figure 1. Nucleotide Sequence of MDJ1 and Predicted Amino Acid Sequence

Two potential TATA boxes are boxed, and the weak matches to the heat shock element (TTCnnGAA) are overlined, with the exact nucleotide matches underlined. A hexanucleotide repeat, previously noted by Praekelt and Meacock (1990), is contained within a polypurine tract between nucleotides -653 and -641 and is marked by dots above the sequence. Five copies of a CCCCT motif, which has previously been reported to be involved in heat shock factor-independent gene induction (Kobayashi and McEntee, 1993), are present upstream of the MDJ1 start ATG codon and are underlined. Restriction enzyme recognition sites referred to in the text are indicated and underlined. 


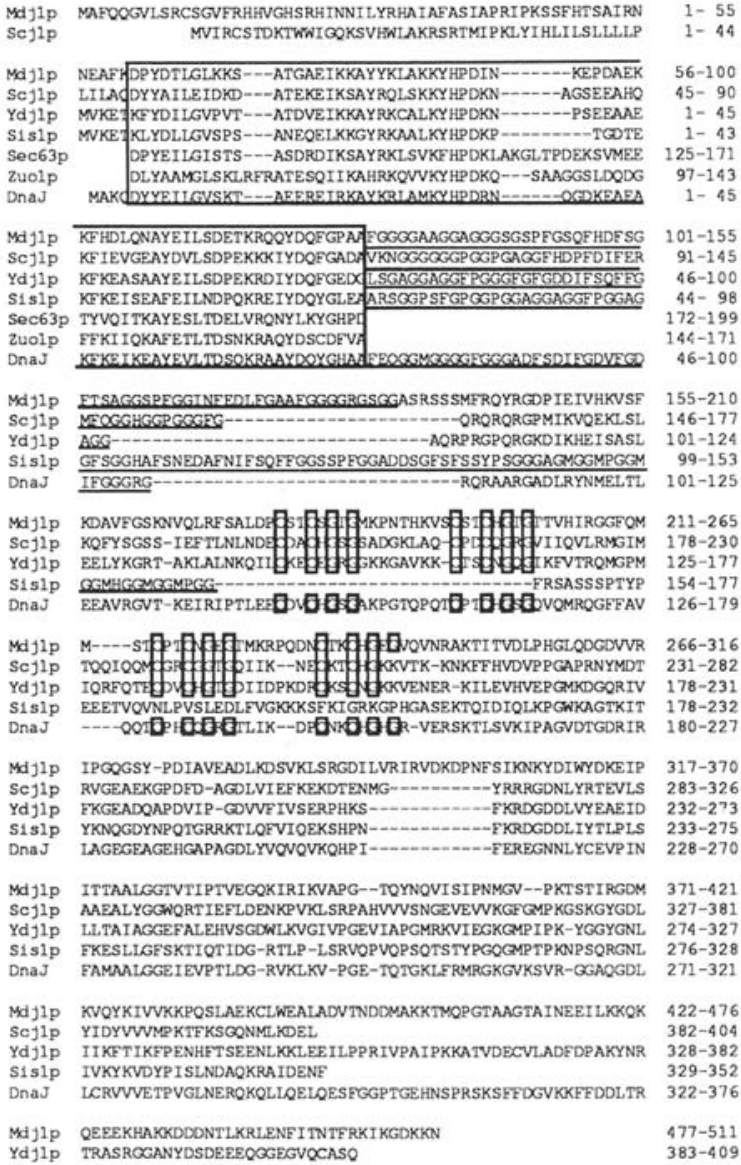

Figure 2. Amino Acid Sequence Comparison of Mdj1p with Other Yeast DnaJ Homologs and E. coli DnaJ

The alignments were performed with the Genetic Computer Group program (University of Wisconsin). The highly conserved $\mathrm{J}$ region is boxed, the glycine-rich stretches are underlined, and the conserved residues of the four cysteine-containing motifs (CxxCxGxG) are boxed. For Sec63p and Zuo1p only, the $\mathrm{J}$ region is shown (residues 125-199 and 97-171, respectively) because only this region shows similarity to the other members of the protein family. Dned (Bardwell et al., 1986); SEC63 (Rothblatt et al., 1989); YDJ1 (Caplan and Douglas, 1991); SIS1 (Luke et al., 1991); SCJ1 (Blumberg and Silver, 1991); and ZUO1 (Zhang et al., 1992)

growth defect was relieved by transformation with a plasmid (pMDJ315) containing the complete $M D J 1$ coding and regulatory sequences. However, the transformed strain (YNR5c) remained petite and failed to grow on nonfermentable carbon sources.

The cells containing the disruption in MDJ1 had lost their mitochondrial DNA (i.e., they were in the rho ${ }^{\circ}$ state). This was concluded from the lack of restoration of respiratory

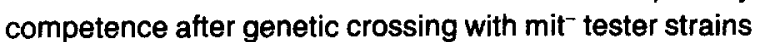
(possessing point mutations in the mitochondrial genome) from fluorescence microscopy of DAPI-stained cells and the absence of mitochondrial DNA bands in $\mathrm{CsCl}$ gradients (data not shown).

We conclude that the inability of the mdj1-disrupted cells to grow at elevated temperatures is directly related to the lack of the MDJ1 gene product and that Mdj1p is required for the maintenance of mitochondrial DNA. The MDJ1
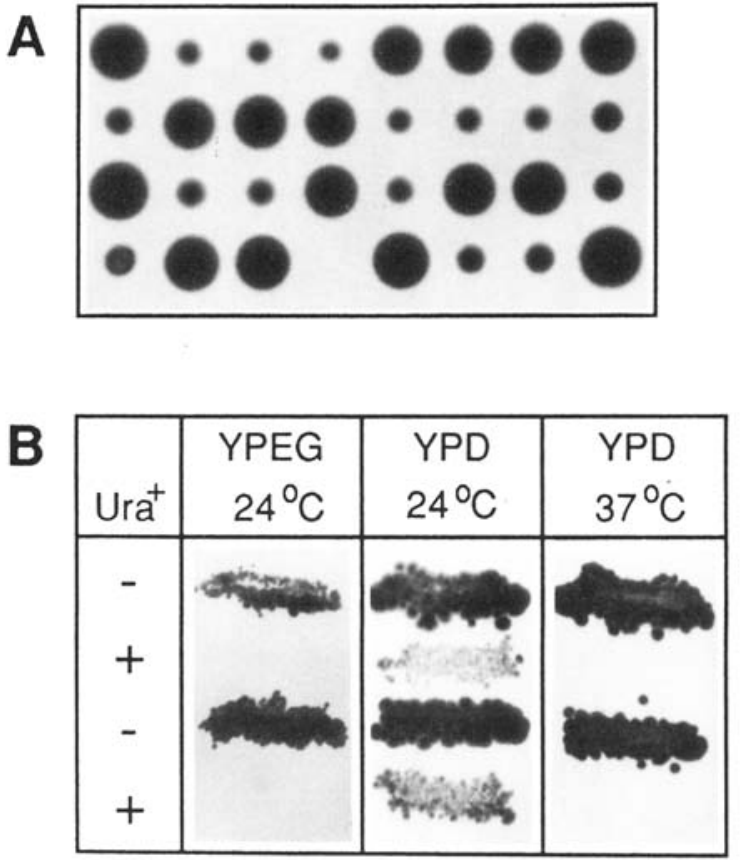

Figure 3. Disruption of the MDJ1 Gene Results in Slow-Growth and Conditional-Lethal Phenotypes

(A) Dissection of tetrads after sporulation of an MOJ1 heterozygous diploid (a/ $\alpha$ YNR3). Dissected tetrads were incubated for 6 days at $30^{\circ} \mathrm{C}$.

(B) Replica-plate analysis of a single dissected tetrad from (A). Yeast cells were grown on a fresh YPD plate and were replica-plated to YPD plates at $24^{\circ} \mathrm{C}$ or $37^{\circ} \mathrm{C}$ or were replica-plated to YPEG plates at $24^{\circ} \mathrm{C}$. Ura $^{+}$, uracil prototrophy.

gene product is therefore essential for normal mitochondrial function.

\section{Mdip is Located on the Matrix Side of the Inner Mitochondrial Membrane}

The predicted Mdj1p sequence contains an amino-terminal extension relative to the $\mathrm{E}$. coli DnaJ gene product with the characteristics of a mitochondrial targeting sequence (Hartl et al., 1989). Two approaches were used to analyze the subcellular location of Mdj1p. First, antibodies were raised against the carboxy-terminal half of Mdj $1 \mathrm{p}$ and were used for immunoblotting of yeast subcellular fractions. As shown in Figure 4A, Mdj1p was observed in the mitochondrial fraction and could not be detected in the cytosolic or nonmitochondrial membrane fractions.

In the second approach, radiolabeled Mdj1p was synthesized in vitro and was incubated with isolated yeast mitochondria. A major translation product with the apparent molecular mass of $55 \mathrm{kd}$ was observed and was imported into a protease-protected location. Import was dependent upon a membrane potential and was accompanied by processing to a $49 \mathrm{kd}$ protein (Figure $4 \mathrm{~B}$ ). The predicted amino acid sequence of the Mdj1p precursor contains a typical matrix processing site (Arretz et al., 1991) between residues 55 and 56 (IRN/N) that is consistent with the apparent $6 \mathrm{kd}$ difference in molecular weight observed upon import and processing. Both the precursor and the mature Mdj1p 

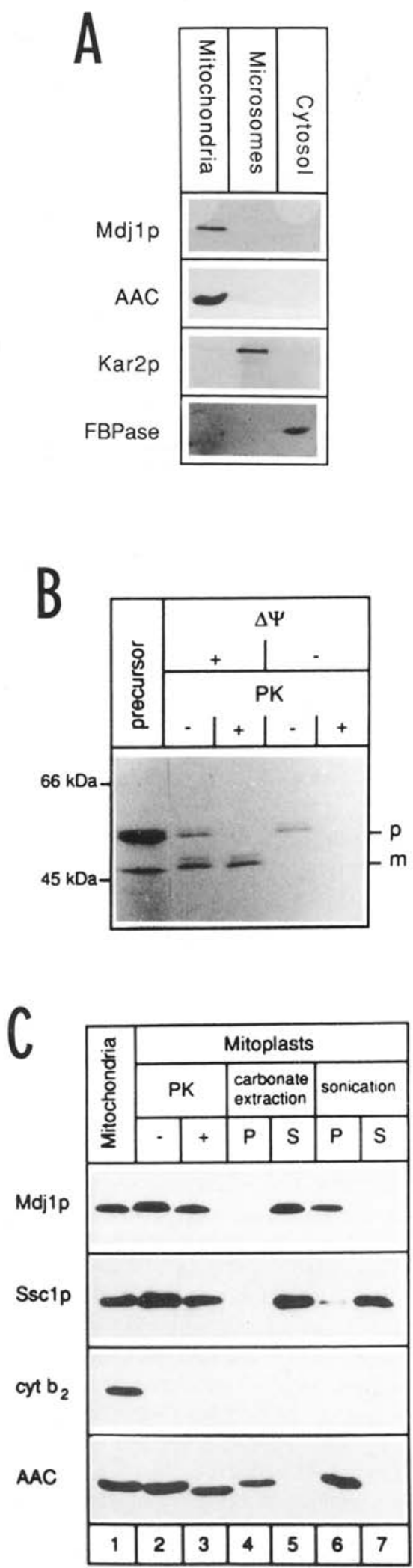

Figure 4. Biochemical Localization of Mdjip

(A) Subcellular localization. Markers for the different subcellular fractions were ADP/ATP carrier for mitochondria, Kar2p for microsomes (the monoclonal antibody against the HDEL peptide used preferentiality recognized Kar2p), and fructose 1,6-bisphosphatase (FBPase) for cytosol. appeared as two closely associated bands after denaturing gel electrophoresis (Figure 4B). The double bands were also sometimes observed on immunoblots using antiserum against Mdj1p, and they probably arise during electrophoresis (similar double bands have been observed with Ydj1p; D. Cyr, personal communication).

To examine the submitochondrial location of Mdj1p, mitochondria were converted into mitoplasts by incubation in hypotonic buffer in the presence of protease. Mdj1p was protected from degradation by proteinase $\mathrm{K}$ (Figure $4 C)$, but was degraded when the inner membrane was disrupted by sonication (not shown). To address the question of whether Mdj1p is a soluble or a membrane-bound protein, mitoplasts were opened by sonication and fractionated into soluble and membrane components. Mdj1p was recovered solely in the vesicle fraction, whereas most of the soluble matrix proteins were recovered in the nonmembrane fraction (Figure 4C). Furthermore, Mdj1p remained bound to the membrane after floating the membrane pellet in a sucrose step gradient containing $2.5 \mathrm{mM}$ EDTA. This excluded the possibility that Mdj1p is associated with the membrane pellet nonspecifically owing to aggregation or association with the ribosomes (data not shown). After carbonate extraction of the mitoplasts, virtually all of the Mdj1p was obtained in the nonmembrane fraction (Figure 4C). These data imply that Mdj1p is a peripheral membrane protein located on the matrix side of the mitochondrial inner membrane.

\section{Mdj1p Is Not Essentlal for Mitochondrial Protein Import}

To investigate whether Mdj1p has a role in mitochondrial protein import, we tested the ability of mitochondria isolated from $\Delta m d j 1$ cells to import radiolabeled precursor proteins in vitro. As a control, protein import into mitochondria of both an isogenic wild-type and an isogenic $r 0^{\circ}$ (YNR5c) strain was examined.

The import efficiency and kinetics of a series of in vitrotranslated precursor proteins was studied. No significant difference in the import kinetics was observed for the $\Delta m d j 1$ mitochondria relative to the rho $0^{\circ}$ control at $25^{\circ} \mathrm{C}$,

(B) Import of in vitro-synthesized Mdj1p precursor into isolated mitochondria. Mdj1p precursor protein was synthesized in reticulocyte lysate and was incubated for $20 \mathrm{~min}$ at $25^{\circ} \mathrm{C}$ with isolated mitochondria from the wild-type S. cerevisiae strain, D273-10B. After the import reaction, samples were treated with proteinase $\mathrm{K}$ where indicated (PK). Dissipation of the membrane potential $(\triangle ' Y)$ was achieved by the addition of carbonyl cyanide m-chiorophenylhydrazone (CCCP) to a final concentration of $30 \mu \mathrm{M}$ prior to import. As a control, $40 \%$ of the precursor protein added to imports was loaded. p, precursor Mdj1p; m, mature Mdj1p.

(C) Submitochondrial localization. Lane 1, intact mitochondria; lane 2, mitoplasts; lane 3, proteinase K-treated mitoplasts; lane 4, membrane protein fraction after carbonate extraction of mitoplasts; lane 5 , soluble protein fraction after carbonate extraction of mitoplasts; lane 6, vesicle fraction after sonication of mitoplasts; and lane 7, soluble matrix protein fraction after sonication of mitoplasts. Marker proteins for the different mitochondrial subcompartments were cytochrome b2 (cyt $\left.b_{2}\right)$ for the intermembrane space; ADPIATP carrier (AAC) for the inner membrane; and Ssc1p (mitochondrial Hsp70) for soluble matrix proteins. Note that proteinase $K$ treatment of mitoplasts generated the typical degradation fragment of the AAC (Rassow and Pfanner, 1991). 


\begin{tabular}{|c|c|c|c|c|c|c|c|c|}
\hline \multirow[t]{3}{*}{ A } & \multirow{3}{*}{ 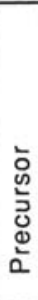 } & \multicolumn{2}{|c|}{$\Delta m d j 1$} & \multicolumn{2}{|c|}{ WT } & \multicolumn{2}{|c|}{$\mathrm{rho}^{\circ}$} & \\
\hline & & \multicolumn{6}{|c|}{ time (min) } & \\
\hline & & -+ & & $\begin{array}{r}P \\
-+\end{array}$ & - + & $-\quad+$ & & \\
\hline $25^{\circ} \mathrm{C}$ & I- & & $=$ & $=$ & $=$ & & $=$ & \begin{tabular}{|l}
$\mathrm{p}$ \\
$\mathrm{m}$
\end{tabular} \\
\hline $30^{\circ} \mathrm{C}$ & & $=$ & $=$ & $=$ & $=$ & $=$ & $=$ & $\begin{array}{l}\mathrm{p} \\
\mathrm{m}\end{array}$ \\
\hline $37^{\circ} \mathrm{C}$ & & - & $=$ & - & $=$ & - & - & $\begin{array}{l}p \\
m\end{array}$ \\
\hline
\end{tabular}

\begin{tabular}{|c|c|c|c|c|c|c|c|c|c|c|}
\hline \multirow[t]{4}{*}{ B } & \multirow{4}{*}{ 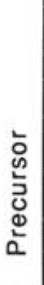 } & \multicolumn{3}{|c|}{$\Delta m d j 1$} & \multicolumn{3}{|c|}{ WT } & \multicolumn{3}{|c|}{$\mathrm{rho}^{\circ}$} \\
\hline & & \multicolumn{9}{|c|}{ time $(\min )$} \\
\hline & & 5 & 10 & 20 & 5 & 10 & 20 & 5 & 10 & 20 \\
\hline & & & -+ & -+ & $-\quad+$ & $\begin{array}{l}\mathrm{PK} \\
-+\end{array}$ & -+ & -+ & & $-\quad+$ \\
\hline $\begin{array}{l}p \\
i \\
m\end{array}$ & & & & & & & - & $=$ & $E=$ & $=$ \\
\hline
\end{tabular}

Figure 5. Import of Radiolabeled Precursor Proteins into Isolated Mitochondria

Mitochondria from the $\Delta m d j 1$ strain, the isogenic wild-type (WT), and the isogenic rho ${ }^{\circ}$ strain were analyzed.

(A) Import of $F, \beta$ at $25^{\circ} \mathrm{C}, 30^{\circ} \mathrm{C}$, or $37^{\circ} \mathrm{C}$. Mitochondria were preincubated at the respective temperatures for $10 \mathrm{~min}$ prior to addition of the radiolabeled precursor protein. After $2.5 \mathrm{~min}$ or $5 \mathrm{~min}$, respectively, the import reaction was stopped by addition of $4 \mathrm{vol}$ of ice-cold SMKCl $(250 \mathrm{mM}$ sucrose, $80 \mathrm{mM} \mathrm{KCl}, 10 \mathrm{mM}$ MOPS$\mathrm{KOH}$ [pH 7.2]) and $1 \mu \mathrm{M}$ valinomycin. One half of each sample was treated with proteinase $K$ $(P K)$, and the other half remained untreated. As a control, nontreated precursor protein is shown.

(B) Import of the Rieske Fe-S protein. The import reaction was performed at $25^{\circ} \mathrm{C}$ for $5 \mathrm{~min}$, $10 \mathrm{~min}$, or $25 \mathrm{~min}$ and was stopped as described above. Again, one half of each sample was proteinase $\mathrm{K}$-treated. $\mathrm{p}$, precursor; $\mathrm{i}$, intermediate; $m$, mature form. $30^{\circ} \mathrm{C}$, and $37^{\circ} \mathrm{C}$ with the $F_{1} B-A T P a s e$ precursor (Figure $5 A)$. Similar results were obtained with the precursors of cytochrome b2, MOM38, cytochrome c heme lyase, ADP/ ATP carrier, and Mdj1p, which were all imported with the same efficiency into mitochondria isolated from the $\Delta m d j 1$ and rho $^{\circ}$ strains (data not shown).

The only precursor whose processing pattern differed in mitochondria of the $\Delta m d j 1$ strain relative to the controls was the Rieske iron-sulphur ( $\mathrm{Fe}-\mathrm{S}$ ) protein. This precursor was efficiently imported into mitochondria from the $\Delta m d j 1$ strain, but the second processing step (by the mitochondrial intermediate processing peptidase) was strongly reduced relative to the controls (Figure $5 \mathrm{~B}$ ). The same reduction in mature form was also observed after immunoblotting of $\Delta m d j 1$ mitochondrial protein with antiserum against the $\mathrm{Fe}-\mathrm{S}$ protein (data not shown), indicating that the intermediate form of $\mathrm{Fe}-\mathrm{S}$ protein accumulates in $\Delta m d j 1$ mitochondria.

\section{Mitochondria Lacking Mdj1p Show a Deficiency in Protein Folding of Newly Imported Precursor} The possible involvement of Mdj1p in the processes of protein folding was investigated. The Su9-DHFR fusion protein, which consists of the presequence of Neurospora crassa $F_{0}$-ATPase subunit 9 preceding the complete mouse dihydrofolate reductase (DHFR) (Pfanner et al., 1987), was imported into mitochondria isolated from
$\Delta m d j 1$ and from isogenic wild-type and rho ${ }^{\circ}$ cells. As a measure of correct protein folding, protease resistance of the processed DHFR fusion protein was determined at various time intervals after import.

Urea-denatured precursor protein was efficiently imported into mitochondria from all three strains at $25^{\circ} \mathrm{C}$ (Figure 6A). After solubilization of mitochondria with digitonin, soluble and nonsoluble fractions were separated by centrifugation. Both fractions were then treated with 10 $\mu \mathrm{g} / \mathrm{ml}$ proteinase $\mathrm{K}$, as folded DHFR has been shown to be resistant to this concentration of the protease (Ostermann et al., 1989). A striking difference was observed between the levels of protease-sensitive insoluble protein in the wild-type and $\Delta m d j 1$ mitochondria; $20 \%$ of the imported protein was found in aggregates (Figure 6A). There was a markedly lower level of insoluble aggregates in mitochondria isolated from the isogenic rho control strain, indicating that this accumulation was directly related to the absence of Mdj1p and was not due to the rho ${ }^{\circ}$ state of the mitochondria.

A more pronounced difference was observed when import reactions were performed at $37^{\circ} \mathrm{C}$ (Figure 6B). After a 6 min import reaction, a negligible amount of aggregated DHFR was detected in mitochondria isolated from the wildtype strain, compared with $25 \%$ and $70 \%$ of the imported protein recovered in the insoluble fraction of the rho ${ }^{\circ}$ and $\Delta m d j 1$ mitochondria, respectively. This aggregated form 
A
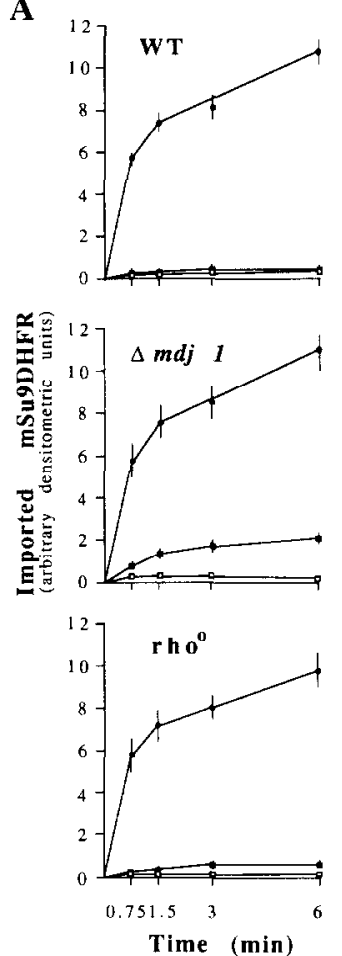

B
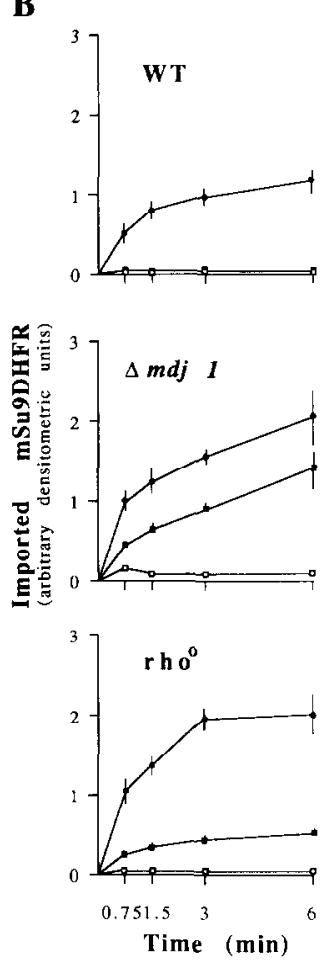

Figure 6. Folding of DHFR Imported into Mitochondria In Vitro

The ability to fold DFHR of mitochondria isolated from wild-type (WT), null mutant ( $\Delta$ mdj1), and null mutant complemented with $M D J 1$ (rho ${ }^{\circ}$ ) was analyzed at $25^{\circ} \mathrm{C}(\mathrm{A})$ and $37^{\circ} \mathrm{C}(\mathrm{B})$. Mitochondria were preincubated for $3 \mathrm{~min}\left(25^{\circ} \mathrm{C}\right)$ or $10 \mathrm{~min}\left(37^{\circ} \mathrm{C}\right)$ prior to the addition of ureadenatured radiolabeled Su9-DHFR precursor. After the indicated time periods, the import reaction was stopped, and nonimported Su9DHFR precursor was digested by trypsin treatment. The reisolated mitochondria were then solubilized with $0.4 \%$ digitonin, and aggre. gated proteins were sedimented. The folding state of the soluble (supernatant) and insoluble (pellet) fractions of DHFR were analyzed by treatment with $10 \mu \mathrm{g} / \mathrm{ml}$ proteinase $\mathrm{K}$. The amount of imported matureform Su9-DHFR present in the pellet and the supernatant was measured by densitometry of SDS-PAGE fluorographs. The results are expressed in arbitrary densitometric units as the mean \pm SEM of three independent experiments. The total amount of imported DHFR is indicated by closed circles, DHFR present in the pellet before proteinase $\mathrm{K}$ treatment is indicated by closed squares, and DHFR present after proteinase $\mathrm{K}$ treatment is indicated by open squares.

of the DHFR protein was found to be completely imported into the matrix and did not represent an import intermediate as it cofractionated with matrix markers after digitonin extraction (data not shown). The observed increase in levels of insoluble protein in the $\Delta m d j 1$ mitochondria at $37^{\circ} \mathrm{C}$ compared with $25^{\circ} \mathrm{C}$, and relative to the controls at either temperature, is suggestive of a block at a specific stage in the protein folding process in $\Delta m d j 1$ mitochondria at the elevated temperature.

To investigate the apparent block in protein folding with a protein whose native conformation can be directly tested by the enzymatic activity, a hybrid protein consisting of the Su9-ATPase presequence fused to firefly luciferase was imported into mitochondria isolated from the $\Delta m d j 1$ and control yeast strains. After import at $25^{\circ} \mathrm{C}$, folding of the imported luciferase protein to the native conformation was monitored by the level of enzymatic activity and was

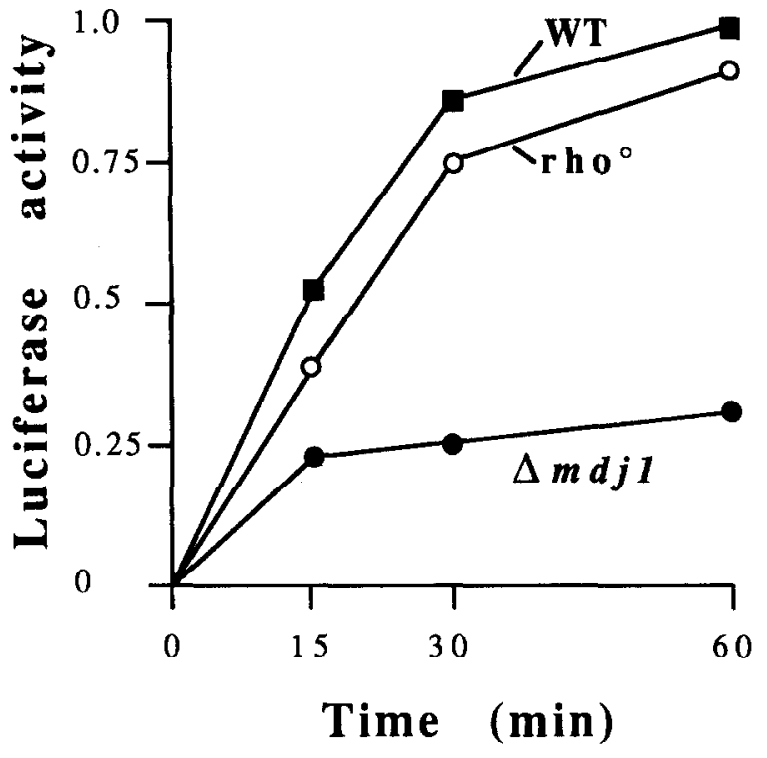

Figure 7. Folding of Firefly Luciferase Is Impaired in Amdj1 Mitochondria

Urea-denatured Su9-luciferase precursor was imported into mitochondria from the wild-type strain (WT), $\Delta$ mdj1, and null mutant complemented with $M D J 1$ ( $\mathrm{rho}^{\circ}$ ). As indicated, the import was stopped, and proteinase K treatment was performed to digest nonimported Su9luciferase precursor. Half of each sample was used to measure luciferase activity, and the other half was subjected to SDS-PAGE to determine the import efficiency so as to correlate this with the luciferase activity for each strain.

correlated with the total amount of protein imported. As shown in Figure 7, luciferase enzyme activity in $\Delta m d j 1$ mitochondria was reduced by $70 \%$ relative to the controls. This result thus supports our conclusion that Mdj1p is actively involved in processes that mediate the folding of newly imported proteins.

\section{Heat Treatment of $\Delta m d j 1$ Mitochondria Leads to the Accumulation of Misfolded Protein Aggregates}

Mdj1p is a heat shock protein, and therefore we investigated the possible involvement of Mdj1p in protecting heat-denatured protein from aggregation. Su9-DHFR fusion protein was imported into mitochondria of the $\Delta m d j 1$, isogenic wild-type, and isogenic $\mathrm{rho}^{\circ}$ strains. After an import time of $6 \mathrm{~min}$ at $25^{\circ} \mathrm{C}$, nonimported precursor was digested with trypsin, and the mitochondria were incubated at $40^{\circ} \mathrm{C}$ for different intervals of time. Protease sensitivity of DHFR was determined as a percentage of the total imported material. The level of protease-resistant material decreased markedly in the isolated $\Delta m d j 1$ mitochondria relative to the controls, which showed a decrease of approximately $20 \%$ over a period of $\mathbf{4 5} \mathrm{min}$ (Figure $\mathrm{BA}$ ). Prolonged incubation of mitochondria at $25^{\circ} \mathrm{C}$ and $30^{\circ} \mathrm{C}$ did not result in an increase in protease sensitivity (Figure $8 \mathrm{~B})$. Therefore, the decrease in the levels of proteaseresistant (native) DHFR at elevated temperature in the $\Delta m d j 1$ mitochondria was a direct consequence of heat denaturation of the imported protein.

In summary, these results indicate that Mdj1p plays a 
A

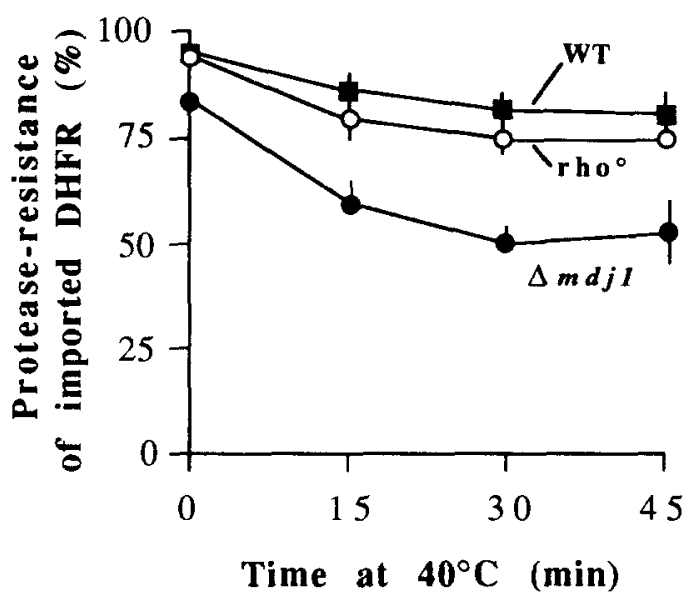

B

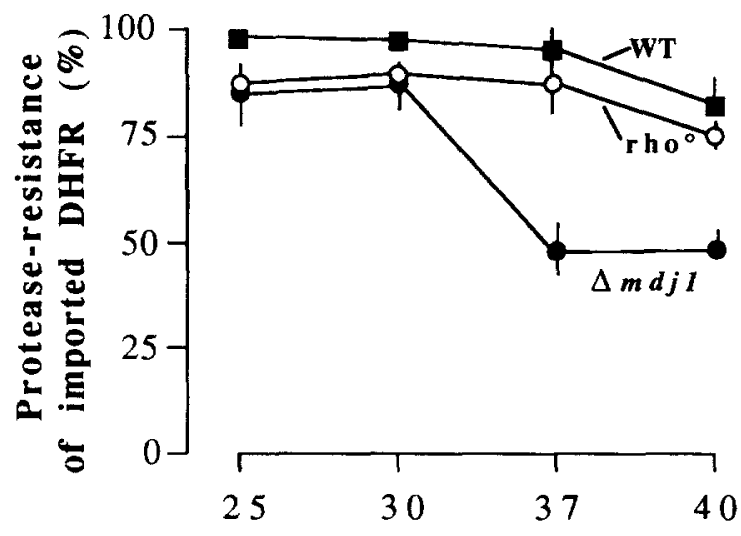

Temperature $\left({ }^{\circ} \mathrm{C}\right)$

Figure 8. Accumulation of Incorrectly Folded DHFR upon Heat Treatment

Urea-denatured Su9-DHFR precursor was imported for $6 \mathrm{~min}$ at $25^{\circ} \mathrm{C}$. The import reaction was then stopped, and trypsin digestion was performed. The mitochondria were then reincubated at $40^{\circ} \mathrm{C}$ for different time periods (A) or at different temperatures for $30 \mathrm{~min}(B)$. Aliquots were removed and were lysed with digitonin, and proteinase $K$ sensitivity of the extracts was determined. The total amount of both proteaseresistant and protease-sensitive material was set equal to $100 \%$. The results represent the mean of two to four independent experiments.

role in the prevention of heat-induced protein aggregation after proteins have been folded to the native conformation.

\section{Discussion}

Mitochondrial Hsp70, Ssc1p, has been shown to play a central role in various processes of mitochondrial biogenesis. It is required for the translocation of many proteins across the mitochondrial membranes, and it is critical for the unfolding of precursor polypeptides outside the mitochondria during translocation (reviewed by Neupert et al., 1990; Neupert and Pfanner, 1993). However, it remains to be determined whether Ssc1p, in conjunction with ATP, is alone sufficient for these functions or whether additional components are involved in these rather complex reactions. The expectation that additional proteins are involved has been nourished by the observation that in $\mathrm{E}$. coli the Hsp70 homolog, DnaK, acts in concert with two other heat shock proteins, DnaJ and GrpE (reviewed by Georgopoulos, 1992). Furthermore, in S. cerevisiae, the Hsp70 homologs Ssa1p and Kar2p are thought to interact with the DnaJ homologs Ydj1p and Sec63p, respectively (Caplan et al., 1992; Sadler et al., 1989; Feldheim et al., 1992).

The yeast heat shock protein described here, Mdj1p, is essential for cell viability at $37^{\circ} \mathrm{C}$, but not at $30^{\circ} \mathrm{C}$. Furthermore, Mdj1p is necessary for maintenance of mitochondrial DNA. Thus, MDJ1 is essential for the formation of mitochondria competent for oxidative phosphorylation.

So what is the function of Mdj1p? Mitochondria, and consequently mitochondrial protein import, are indispensible in eukaryotic cells. In agreement with this notion, our experiments do not suggest an essential role for Mdj1p in assisting $\mathrm{Hsp} 70$ in its role of translocating polypeptide chains across the mitochondrial membranes into the matrix. Thus, it seems possible that mitochondrial Hsp70 can perform its role in mitochondrial protein import without the assistance of a DnaJ homolog. However, experiments with isolated mitochondria do not completely rule out some involvement of Mdj1p in these processes.

The lack of Mdj1p resulted in reduced competence of mitochondria to properly fold imported monomeric proteins. At $25^{\circ} \mathrm{C}$, and especially at $37^{\circ} \mathrm{C}$, imported DHFR had a propensity to aggregate in the null mutant mitochondria; the aggregated form was protease sensitive and, therefore, was in an improperly folded state. In contrast, almost no misfolded DHFR accumulated in wild-type mitochondria. Furthermore, when the $\Delta$ mdj1 strain was complemented with the MDJ1 gene on a plasmid, the ability to correctly fold DHFR was restored to a large extent. Thus, the aggregation of imported DHFR in the null mutant is not due to the rho ${ }^{\circ}$ state of the mitochondria, but is specifically related to the lack of Mdjip.

Even more compelling evidence for a role of Mdj1p in protein folding reactions was obtained by assessing the amount of enzymatically active luciferase in $\Delta m d j 1$ mitochondria after import in vitro. These mitochondria showed a $70 \%$ reduction in luciferase activity compared with the controls at physiological temperature. We therefore conclude that Mdj1p is involved in the folding of newly imported precursor proteins, and in particular, Mdj1p is important for folding at elevated temperature. Mdj1p does not only play a role in the folding of newly imported proteins, but it also appears to prevent aggregation of folded proteins.

The degree of Mdj1p-mediated protection against heat denaturation and its requirement for protein folding probably depends upon the protein. DHFR and luciferase are nonmitochondrial tester proteins, and therefore the observed effects in the null mutant mitochondria may be in- 
termediate. Accordingly, the lethality of mdj1 disruption at elevated temperature may be a result of the dysfunction of a set of proteins that are critical for cell viability.

The means by which both protein folding and protection processes are mediated by Mdj $1 p$ remains to be analyzed. Very likely, Mdj1p cooperates with mitochondrial Hsp70 in these processes, although this leaves the intriguing question of why such cooperation is apparently unnecessary for the function of Hsp7O in the translocation of proteins into mitochondria. One could imagine that the binding of $\mathrm{Hsp} 70$ to the incoming unfolded precursor does not need to be promoted by a DnaJ-like protein, as components of the import apparatus could present the extended polypeptide chain to Hsp70. Furthermore, it cannot be excluded that a second DnaJ-like component may reside in the mitochondria and cooperate with Hsp70 specifically in the translocation process. It is very unlikely that this DnaJ homolog is Scj1p (Blumberg and Silver, 1991), since Scj1p is probably not localized in mitochondria and since Scj1, Mdj1 double mutants were found to be viable (P. Silver, personal communication; N. R., unpublished data).

Any discussion of protein folding has to consider the role of Hsp60 (the MIF4 gene product) in these processes. In a recent in vivo analysis of a temperature-sensitive mif4 allele, Martin et al. (1992) described a strikingly similar reduction in the levels of folded mitochondrial protein as that which we observe in vitro with mitochondria of the mdj1 disruption strain. Consistent with a model of the protein folding processes (Langer et al., 1992) where GroEL/ ES acts in a step subsequent to DnaK, DnaJ, and GrpE, the absence of Mdj1p could result in a similar phenotype as that of an Hsp60 mutation. Consequently, this would imply that Mdj1p Itself is required for the action of Hsp60; this could be explained if Mdj1p mediates the passage of polypeptides to Hsp60.

The data presented here provide the first indication for a function of a DnaJ homolog in protein folding in eukaryotic cells. Thus, our conclusions conform with the findings by Langer et al. (1992) and by Schröder et al. (1993), which suggest an important role for DnaJ in protein folding based upon the folding of proteins in a reconstituted system, including DnaK, DnaJ, and GrpE, and the reactivation of heat-inactivated luciferase.

The observation that MDJ1 disruption causes loss of mitochondrial DNA is intriguing. Deficiency of protein folding in mitochondria lacking Mdj1p may indirectly influence mitochondrial translation and thereby DNA replication, as mitochondrial DNA replication has been shown to be dependent upon ongoing translation (Myers et al., 1985). Since the DnaJ homolog Sis1p is directly involved in cytosolic translation (Zhong and Arndt, 1993), Mdj1p might also play a direct role in mitochondrial protein synthesis, which could then explain the loss of mitochondrial DNA in the null mutant. Alternatively, it is also conceivable that Mdj1p plays a direct role in mitochondrial DNA replication, as its $E$. coli homolog, DnaJ, is involved in bacteriophage $\lambda$ and phage P1 DNA replication (Zylicz et al, 1989; Wickner et al., 1991).

Mdj1p constitutes an additional mitochondrial protein that appears to have been conserved during the evolution of mitochondria from their endosymbiontic ancestors. Like its prokaryotic homolog in E. coli, DnaJ, Mdj1p is involved in processes such as protein folding and protection against heat denaturation. Its role in mitochondrial DNA replication and protein synthesis remains to be determined. It is however, tempting to speculate that, similar to the situation in the prokaryotic system, Mdj1p exerts its functions in cooperation with Ssc1p and possibly also with a mitochondrial homolog of bacterial GrpE.

\section{Experimental Procedures}

\section{Culture Conditions and Genetic Analysls}

Yeast cell growth conditions, sporulation, and tetrad dissection were performed according to Sherman et al. (1986). Yeast cells were made competent for transformation by the DMSO-enhanced method (Hill et al., 1991).

\section{Strains and Plasmids}

For biochemical analysis, mitochondria and other subcellular fractions were prepared from yeast strain D273-10B. For genetic analysis, yeast strain a/a735 (Newman and Norman, 1991) and its derivatives were used. The disrupted heterozygous diploid was named a/aYNR3 (a/a735 with MDJ1/maj1::URA3). A spore disrupted in MDV1 derived from the tetrad analysis of a/a YNR3 and further investigated is referred to as YNR5 (MATa mdj1::URA3). The isogenic rho ${ }^{\circ}$ control strain was constructed by transforming strain YNR5, which had lost its mitochondrial DNA, with a CEN plasmid pMDJ315, yielding strain YNR5c. pMDJ315 contains the MDJ1 coding and regulatory sequences on a $2.8 \mathrm{~kb}$ Hindlil-Sacl fragment of $\lambda$-cloned yeast genomic DNA inserted into pRS315 (SIkorski and Hleter, 1989). As confirmed by immunoblotting, the level of expression of Mdj $1 \mathrm{p}$ in the complemented strain was similar to that in the wild-type (data not shown). The bacterial host strains used were TG1 (Gibson, 1984) and XL1 blue (Stratagene) for the overexpression of recombinant protein. To express the MDJ1 gene in vitro, a PCR fragment, MJ23, containing the coding sequence of $M D J 1$ was inserted into the expression vector pGEM4, placing the MDJ1 coding sequences under the control of the SP6 promoter.

\section{DNA Sequencing}

The mapped library of $\lambda$ and cosmid clones of $\mathbf{S}$. cerevisae (strain AB972) was supplied by M. Olson (Olson et al., 1986; Riles et al., 1993). A random sequencing strategy (Bankier et al., 1987) was used to generate DNA sequence by the chain termination method (Sanger et al., 1977) using fluorescence-tagged dye primers and an ABI 370A fluorescent sequencer (Smith et al., 1993). The sequence was determined on both strands and compiled with the XBAP computer program (Dear and Staden, 1991). Nucleotide and protein comparisons were performed with the FASTA program (Pearson and Lipman, 1988) against the PIR (release 31, 1991), SWISS PROT (release 20, 1991) and the EMBL (release 29, 1991) databases.

Southern Blot Analysis and Construction of PCR Fragments Total genomic DNA was isolated from yeast cells as described by Philippsen et al. (1991), and Southern blot analysis was performed as described (Southern, 1975). DNA probes were prepared by PCR and labeled with [ [" P] $\alpha$ dCTP (Amersham) by random priming (Pharmacia) PCR fragments MJ13 and MJ23 were generated using $5^{\prime}$ primers: MJ1, 5'-GGTCTAGAGATGGAAGTACGCTCAAAAG-3', bases -231211; and MJ2, 5'-CCTAAAGCTTACTCTAAACATAACATAAC-3', bases $-19-4$, respectively; and the 3'primer MJ3 (5'-CCTAAAGCTTACTCTAAACATAACATAAC-3', bases 1746-1766).

Hybridization of radiolabeled DNA probes and subsequent washing steps were performed under stringent conditions at $65^{\circ} \mathrm{C}$ (Church and Gilbert, 1984).

\section{Disruption of the MDJ1 Gene}

A disruption allele of $M D J 1$ was constructed in plasmid pdj6-1 by inserting a blunt-ended $1.1 \mathrm{~kb}$ Smal-Clal fragment from YEp24 containing the URA3 gene into the SnaBI-Bsml sites of the MJ13 PCR fragment cloned into the Smal site of pBS KSI${ }^{+}$. This construct resulted in the deletion of almost the entire mature part of the protein. After 
transformation of strain $a / \alpha 735$, the correct insertion of the URA3 gene into the MDJ1 locus was monitored by PCR and Southern blot analysis.

\section{Subfractionation of Yeast Cells}

Mitochondria of wild-type S. cerevisiae (strain D273-10B) were prepared by differential centrifugation as described (Daum ot al., 1982) and were further purified on a sucrose step gradient consisting of $20 \%$, $30 \%, 40 \%, 50 \%$, and $60 \%$ sucrose (w/w) in $10 \mathrm{mM}$ MOPS-KOH (pH 7.4), $100 \mathrm{mM} \mathrm{KCl}, 1 \mathrm{mM}$ EDTA, and $1 \mathrm{mM}$ PMSF. The gradient was centrifuged at $240,000 \times \mathrm{g}$ for $15 \mathrm{~min}$ at $2^{\circ} \mathrm{C}$ in a Beckman SW41 rotor. Mitochondria were collected from the band between the $40 \%$ and $50 \%$ sucrose layer, were concentrated by centrifugation at 12,000 $\times \mathrm{g}$ for $10 \mathrm{~min}$ at $2^{\circ} \mathrm{C}$, were washed in SEM (250 mM sucrose, $1 \mathrm{mM}$ EDTA, $10 \mathrm{mM}$ MOPS-KOH [pH 7.2]), and finally were resuspended in SEM.

Preparation of microsomes and the cytosolic fraction was essentially carried out as described (Caplan and Douglas, 1991), with the modification that for the preparation of microsomes the micrococcal nuclease treatment was omitted. The membrane band from the $30 \%$ (v/v) Percoll gradient was directly concentrated by pelleting at $150,000 \times \mathrm{g}$ for $1 \mathrm{hr}$ at $2^{\circ} \mathrm{C}$ in a Beckman T150 rotor and was used for immunoblotting.

\section{Subfractionation of Mitochondria}

For generation of mitoplasts, mitochondria were resuspended in icecold hypotonic buffer ( $2 \mathrm{mg} / \mathrm{ml}$ mitochondrial protein, $20 \mathrm{mM}$ HEPES/ $\mathrm{KOH}$ [pH 7.4], $1 \mathrm{mg} / \mathrm{ml} \mathrm{BSA}$ ) and were incubated on ice for $25 \mathrm{~min}$ with gentle vortexing every $5 \mathrm{~min}$. As a control, mitochondria were resuspended in ice-cold isotonic buffer (0.6 M sorbitol, $20 \mathrm{mM}$ HEPES/ $\mathrm{KOH}$ [pH 7.4], $1 \mathrm{mg} / \mathrm{ml}$ BSA) and were incubated on ice without vortexing. For protease treatment of mitoplasts, $100 \mu \mathrm{g} / \mathrm{ml}$ proteinase $\mathrm{K}$ was added to the swelling buffer. Protease treatment was stopped by adding PMSF to a final concentration of $1.5 \mathrm{mM}$, followed by $5 \mathrm{~min}$ of incubation on ice. After swelling, mitoplasts were pelleted by centrifugation at $12,000 \times \mathrm{g}$ for $10 \mathrm{~min}$ at $2^{\circ} \mathrm{C}$. For carbonate extraction, the mitoplasts were resuspended in $0.1 \mathrm{M} \mathrm{Na}_{2} \mathrm{CO}_{3}$ and $1 \mathrm{mM} \mathrm{PMSF}$, were incubated for $30 \mathrm{~min}$ on ice, and were centrifuged at 226,000 $\times \mathrm{g}$ for $1 \mathrm{hr}$ at $2^{\circ} \mathrm{C}$ in a Beckman Ti50 rotor. The pellet was taken as the membrane protein fraction, and the supernatant was taken as the nonmembrane protein fraction. For sonication, mitoplasts were resuspended in $20 \mathrm{mM}$ HEPES/KOH (pH 7.4), $100 \mathrm{mM} \mathrm{KCl}$, and 1 MM PMSF, were subjected to sonication with a Branson Sonifier 250 connected to a microtip ( $80 \%$ duty cycle, 15 pulses of $10 \mathrm{~s}$ [each] interrupted by $10 \mathrm{~s}$ intervals), and were centrifuged at $226,000 \times \mathrm{g}$ for $1 \mathrm{hr}$ at $2^{\circ} \mathrm{C}$ in a Beckman Ti50 rotor. The pellet was taken as the vesicle fraction, and the supernatant was taken as the soluble matrix protein fraction. All samples were precipitated with trichloroacetic acid as described (Glick et al., 1992). Aliquots were then subjected to SDSPAGE (Laemmli, 1970), and immunoblotting of protein to nitrocellulose was performed.

Preparation of Antiserum and Immunoblotting

The carboxy-terminal half of MDJ1 (consisting of 235 residues) was subcloned into the E. coli expression vector pQE10 (QIAGEN), and the recombinant protein was purified as inclusion bodies according to the instructions of the manufacturer. Antiserum was prepared by the injection of denatured protein into a Chinchilla bastard rabbit. The rabbit was boosted after 3 and 6 weeks, and serum was taken 10 days thereafter.

After SDS-PAGE, immunoblotting to nitrocellulose was performed as described (Schwarz et al., 1993). As a second antibody, horseradish peroxidase-coupled antibody was applied. The signal was detected by using the ECL Western blotting system (Amersham) and by exposure to Fuji XR films.

Synthesis of Radiolabeled Proteins and Import In Vitro Radiolabeled precursor proteins were synthesized in reticulocyte lysate as described previously (Pelham and Jackson, 1976; Krieg and Melton, 1984; Stueber et al., 1984).

Isolation of mitochondria and in vitro import of radiolabeled precursor proteins was carried out as described (Schwarz et al., 1993), with the exception that $10 \mathrm{mM}$ phosphocreatine and $100 \mu \mathrm{g} / \mathrm{ml}$ phosphocreatine kinase as an energy regenerating system were added to the import buffer to allow efficient import into mitochondria of the rho ${ }^{\circ}$ strains. After SDS-PAGE and exposure to Kodak XR films, data were quantified by laser densitometry (Ultroscan XL, Pharmacia).

\section{Folding Assay of Mature Su9-DHFR}

The folding assay for DHFR was essentially carried out as described by Ostermann et al. (1989). Su9-DHFR precursor was synthesized in vitro by transcription and translation as described above. Radiolabeled precursor protein was precipitated with $\left(\mathrm{NH}_{4}\right)_{2} \mathrm{SO}_{4}$ at a $66 \%$ saturation for $30 \mathrm{~min}$ at $0^{\circ} \mathrm{C}$, and the precipitate was dissolved in $8 \mathrm{M}$ urea and $10 \mathrm{mM}$ Tris- $-\mathrm{HCl}(\mathrm{pH} 7.5)$. Denatured precursor was diluted 50-fold into import reaction mix containing $0.4 \mathrm{mg} / \mathrm{ml}$ mitochondria. Before addition of Su9-DHFR precursor protein, mitochondria were preincubated in import buffer for $3 \mathrm{~min}$ at $25^{\circ} \mathrm{C}$ or for $10 \mathrm{~min}$ at $37^{\circ} \mathrm{C}$. After this preincubation, precursor protein was added and import was performed either at $25^{\circ} \mathrm{C}$ or $37^{\circ} \mathrm{C}$ for the indicated time periods. The import reaction was stopped by removal of aliquots corresponding to $80 \mu \mathrm{g}$ of protein and by dilution in 4 vol of ice-cold SEM buffer containing 8 $\mu \mathrm{M}$ anti-mycin A, $2.5 \mu \mathrm{M}$ oligomycin, and $1 \mu \mathrm{g} / \mathrm{ml}$ valinomycin. The samples were subsequently treated with $50 \mu \mathrm{g} / \mathrm{ml}$ trypsin for $20 \mathrm{~min}$ at $0^{\circ} \mathrm{C}$. After protease inactivation by $1 \mathrm{mg} / \mathrm{ml}$ soybean trypsin inhibitor, mitochondria were reisolated by centrifugation and were resuspended at a final concentration of $0.5 \mathrm{mg} / \mathrm{ml}$ in $0.4 \%$ digitonin in SEM, $100 \mathrm{mM}$ $\mathrm{KCl}$. After $10 \mathrm{~min}$ at $0^{\circ} \mathrm{C}$, the samples were centrifuged at $16,000 \times$ $\mathrm{g}$ for $10 \mathrm{~min}$ at $2^{\circ} \mathrm{C}$. Haif of both the supernatant and the pellet were treated with $10 \mu \mathrm{g} / \mathrm{ml}$ proteinase $\mathrm{K}$ for $10 \mathrm{~min}$ at $0^{\circ} \mathrm{C}$. After addition of $1 \mathrm{mM}$ PMSF, trichloroacetic acid precipitates were analyzed by SDS-PAGE, fluorography (according to instructions of the manufacturer, Amersham), and densitometry.

\section{Determination of Luciferase Actlvity}

The preparation of radiolabeled precursor of Su9-luciferase (J. Hendrick and F.-U. Hartl, unpublished data) was carried out as described above for Su9-DHFR used in the folding assay. Urea-denatured luciferase was then imported as described above for Su9-DHFR, excep! that the time points taken were 15,30 , and $60 \mathrm{~min}$. The import reaction was stopped by the addition of $8 \mu \mathrm{M}$ anti-mycin $\mathrm{A}, 2.5 \mu \mathrm{M}$ oligomycin, and $1 \mu \mathrm{g} / \mathrm{ml}$ valinomycin. The samples were then washed once in SEM buffer, were resuspended in SEM, $100 \mathrm{mM} \mathrm{KCl}$, and were treated with $200 \mu \mathrm{g} / \mathrm{ml}$ proteinase $\mathrm{K}$ for $30 \mathrm{~min}$ on ice. Subsequently, $1 \mathrm{mM}$ PMSF was added, and the mitochondria were washed in SEM containing $1 \mathrm{mM}$ PMSF. Half of each sample was analyzed by SDS-PAGE to determine the amount of imported protein by densitometry. For the determination of luciferase activity, the second half was resuspended in the import buffer. Luciferase activity from resuspended mitochondria was determined in $350 \mu$ of assay buffer (25 mM glycyi-glycin, 15 $\mathrm{mM} \mathrm{MgSO}, 5 \mathrm{mM}$ ATP [pH 7.8]). The test tube was then placed in a luminometer (Berthold, Lumat LB9501), and the reaction was started by the injection of $0.1 \mathrm{mM}$ luciferin. For each time point, the measured activity was related to the amount of imported luciferase. The specific luciferase activity determined in wild-type mitochondria after $60 \mathrm{~min}$ of import was set to 1 .

\section{Heat Denaturation of Imported DHFR}

Urea-denatured Su9-DHFR was first imported into mitochondria for $6 \mathrm{~min}$ at $25^{\circ} \mathrm{C}$ as described above, except that the import reaction was then stopped by the addition of $1 \mu \mathrm{g} / \mathrm{mI}$ valinomycin. After trypsin digestion of the nonimported protein (see above), the mitochondria were incubated at $40^{\circ} \mathrm{C}$ for 15,30 , and $45 \mathrm{~min}$ or at $25^{\circ} \mathrm{C}, 30^{\circ} \mathrm{C}$, $37^{\circ} \mathrm{C}$, and $40^{\circ} \mathrm{C}$ for $30 \mathrm{~min}$. Samples were then diluted with 4 vol of SEM, were reisolated, and were lysed with $0.4 \%$ digitonin in SEM, $100 \mathrm{mM} \mathrm{KCl}$. Proteinase K sensitivity of the samples was then determined as described above.

\section{Acknowledgments}

C. Prip-Buus and B. Westermann contributed equally to this work. We thank T. Langer for discussion and advice. We would also like to thank Fiona Townsley and Alan Bankier for critical reading of this manuscript. The luciferase construct was kindly provided by J. Hendrick and F.-U. Hartl. Antibody against the fructose 1,6-bisphosphatase was a generous gift from D. Wolf (Stuttgart), and antibody against Kar2p was from M. Lewis (Cambridge). We are grateful to Gabriele Ludwig and Gabi Bader for excellent technical assistance. This work was supported by 
the Genzentrum München, a fellowship of the European Economic Community to C. P-B. (Human Capital and Mobility Program), and the Deutsche Forschungsgemeinschaft through Schwerpunktprogramm Molekulare Zellbiologie der Hítzestressantwort.

Received November 29, 1993; revised February 3, 1994.

\section{References}

Amin, J., Ananthan, J., and Voellmy, R. (1988). Key features of heat shock regulatory elements. Mol. Cell. Biol. 8, 3761-3769.

Arretz, M., Schneider, H., Wienhues, U., and Neupert, W. (1991). Processing of mitochondrial precursor proteins. Biomed. Biochim. Acta 50, 403-412.

Atencio, D. P., and Yaffe, M. P. (1992). MAS5, a yeast homolog of Dnal involved in mitochondrial protein import. Mol. Cell. Biol. 12, 283291.

Bankier, A., Weston, K. M., and Barrell, B. G. (1987). Random cloning and sequencing by the M13/dideoxynucleotide chain termination method. Meth. Enzymol. 155, 51-93.

Bardwell, J. C. A., Tilly, K., Craig, E., King, J., Zylicz, M., and Georgopoulos, C. (1986). The nucleotide sequence of the Escherichia coli K12 dnad gene. J. Blol. Chem. 261, 1782-1785.

Blumberg, H., and Silver, P. A. (1991). A homologue of the bacterial heat-shock gene DnaJ that alters protein sorting in yeast. Nature 349 , 627-629.

Caplan, A. J., and Douglas, M. G. (1991). Characterization of YDJ1: a yeast homologue of the bacterial dnaJ protein. J. Cell Biol. 114, 609-621.

Caplan, A. J., Cyr, D. M., and Douglas, M. G. (1992). YDJ1p facilitates polypeptide translocation across different intracellular membranes by a conserved mechanism. Cell 71, 1143-1155.

Caplan, A. J., Cyr, D. M., and Douglas, M. G. (1993). Eukaryotic homologues of Escherichia coli dnad: a diverse protein family that functions with HSP70 stress proteins. Mol. Biol. Cell 4, 555-563.

Cheng, M. Y., Hartl, F.-U., Martin, J., Pollock, R. A., Kalousek, F., Neupert, W., Hallberg, E. M., Hailberg, R. L., and Horwich, A. L. (1989). Mitochondrial heat-shock protein hsp60 is essential for assembly of proteins imported into yeast mitochondria. Nature 337, 620-625.

Chirico, W. J., Waters, M. G., and Blobel, G. (1988). 70K heat shock related proteins stimulate protein translocation into microsomes. $\mathrm{Na}$ ture 332, 805-810.

Church, G. M., and Gilbert, W. (1984). Genomic sequencing. Proc Natl. Acad. Sci. USA 81, 1991-1995

Craig. E. A., Gambill, B. D., and Nelson, R. J. (1993). Heat shock proteins: molecular chaperones of protein biogenesis. Microbiol. Rev. 57, 402-414.

Daum, G., Bǒhni, P. C., and Schatz, G. (1982). Import of proteins into mitochondria. J. Biol. Chem. 257, 13028-13033.

Dear, S., and Staden, R. (1991). A sequence assembly and editing program for efficient management of large projects. Nucl. Acids Res. 19, 3907-3911.

Deshaies, R. J., Koch, B. D., Werner-Washburne, M., Craig, E. A., and Schekman, R. (1988). A subfamily of stress proteins facilitates translocation of secretory and mitochondrial precursor polypeptides. Nature 332, 800-805.

Ellis, R. J. (1993) The general concept of molecular chaperones Philos. Trans. R. Soc. Lond. 339, 257-261.

Feldheim, D., Rothblatt, J., and Schekman, R. (1992). Topology and functional domains of Sec63p, an endoplasmic reticulum membrane protein required for secretory protein translocation. Mol. Cell. Biol. 12, 3288-3296.

Gamer, J., Bujard, H., and Bukau, B. (1992). Physical interaction between heat shock proteins DnaK, DnaJ, and GrpE and the bacterial heat shock transcription factor $\sigma^{32}$. Cell 69, 833-842.

Georgopoulos, C., (1992). The emergence of chaperone machines. Trends Biochem. Sci. 17, 295-299.

Gibson, T. J. (1984). Studies of the Epstein-Barr virus genome. PhD thesis, University of Cambridge, Cambridge, England.
Glick, B. S., Brandt, A., Cunningham, K., Müller, S., Hallberg, R. L. and Schatz G. (1992). Cytochromes $c_{1}$ and $b_{2}$ are sorted to the intermembrane space of yeast mitochondria by a stop-transfer mechanism. Cell 69, 809-822.

Hartl, F.-U., Planner, N., Nicholson, D. W., and Neupert, W. (1989). Mitochondrial protein import. Biochim. Biophys. Acta 988, 1-45.

Hill, J., lan, K. A., Donald, G., and Griffiths, D. E. (1991). DMSO enhanced whole cell yeast transformation. Nucl. Acids Res. 19, 5791. Kang, P.-J., Ostermann, J., Shilling, J., Neupert, W., Craig, E. A., and Pfanner, N. (1990). Requirement for hsp70 in the mitochondrial matrix for translocation and folding of precursor proteins. Nature $348,137-$ 143.

Kobayashi, N., and McEntee, K. (1993). Identification of cis and trans components of a novel heat shock stress regulatory pathway in Saccharomyces cerevisiae. Mol. Cell. Biol. 13, 248-256.

Krieg, P. A., and Melton, D. A. (1984). Functional messenger RNAs are produced by SP6 in vitro transcription of cloned CDNAs. Nucl. Acids Res. 12, 7057-7070

Laemmli, U. K. (1970). Cleavage of structural proteins during the assembly of the head of bacteriophage T4. Nature 227, 680-685.

Langer, T., Lu, C., Echols, H., Flanagan, J., Hayer, M. K., and Hartl, F.-U. (1992). Successive action of DnaK, DnaJ and GroEL along the pathway of chaperone-mediated protein folding. Nature 356, 683-689.

Liberek, K., Marszalek, J., Ang, D., Georgopoulos, C., and Zylicz, M. (1991). Escherichia coli DnaJ and GrpE heat shock proteins jointly stimulate ATPase activity of DnaK. Proc. Natl. Acad. Sci. USA 88, 2874-2878.

Luke, M. M., Sutton, A., and Arndt, K. T. (1991). Characterization of SIS1, a Saccharomyces cerevisiae homologue of bacterial dnas proteins. J. Cell Biol. 114, 623-638.

Manning-Krieg, U. C., Scherer, P. E., and Schatz, G. (1991). Sequential action of mitochondrial chaperones in protein import into the matrix. EMBO J. 10, 3273-3280

Martin, J., Horwich A. L., and Hartl, F.-U. (1992). Prevention of protein denaturation under heat stress by the chaperonin Hsp60. Science 258, 995-998.

Myers, A. M., Pape, L. K., and Tzagoloff, A. (1985). Mitochondrial protein synthesis is required for maintenance of intact mitochondria genomes in Saccharomyces cerevisiae. EMBO J. 4, 2087-2092.

Neupert, W., and Pfanner, N. (1993). Roles of molecular chaperones in protein targeting to mitochondria. Philos. Trans. R. Soc. Lond. 339 , 355-362.

Neupert, W., Hartl, F.-U., Craig, E. A., and Ptanner, N. (1990). How do polypeptides cross the mitochondrial membranes? Cell $63,447-$ 450.

Newman, A., and Norman, C. (1991). Mutations in yeast U5 snRNA alter the specificity of $5^{\prime}$ splice-site cleavage. Cell $65,115-123$.

Olson, M. V., Dutchik, J. E., Graham, M. Y., Brodeur, G. M., Helms, C., Frank, M., MacCollin, M., Scheinman, R., and Frank, T. (1986). Random-clone strategy for genomic restriction mapping in yeast. Proc Natl. Acad. Sci. USA 83, 7826-7830.

Ostermann, J., Horwich, A. L., Neupert, W., and Hartl, F.-U. (1989) Protein folding in mitochondria requires complex formation with hsp60 and ATP hydrolysis. Nature 341, 125-130.

Pearson, W. R., and Lipman, D. J. (1988). Improved tools for biological sequence comparison. Proc. Natl. Acad. Sci. USA 85, 2444-2448.

Pelham, H. R. B., and Jackson, R. J. (1976). An efficient mRNAdependent translation system from reticulocyte lysates. Eur. J. Biochem. 67, 247-256.

Pfanner, N., Tropschug, M., and Neupert, W. (1987). Mitochondrial protein import: nucleoside triphosphates are involved in conferring import-competence to precursors. Cell 49, 815-823.

Philippsen, P., Stotz, A., and Scherf, C. (1991). DNA of Saccharomyces cerevisiae. Meth. Enzymol. 194, 169-182.

Praekelt, U. M., and Meacock, P. A. (1990). HSP12, a small heat shock gene of Saccharomyces cerevisiae: analysis of structure, regulation and function. Mol. Gen. Genet. 223, 97-106.

Rassow, J., and Pfanner, N. (1991). Mitochondrial preproteins en route 
from the outer membrane to the inner membrane are exposed to the intermembrane space. FEBS Lett. 293, 85-86.

Riles, L., Dutchik, J. E., Baktha, A., McCauley, B. K., Thayer, E. C., Leckie, M. P., Braden, V. V., Depke, J. E., and Olson, M. V. (1993). Physical maps of the six smallest chromosomes of Saccharomyces cerevisiae at a resolution of 2.6 kilobase pairs. Genetics 134, 81-150. Rothblatt, J. A., Deshaies, R. J., Sanders, S. L., Daum, G., and Schekman, R. (1989). Multiple genes are required for proper insertion of secretory proteins into the endoplasmic reticulum in yeast. J. Cell Biol. 109, 2641-2652.

Sadler, ł., Chiang, A., Kurihara, T., Rothblatt, J., Way, J., and Silver, $P$. (1989). A yeast gene important for protein assembly into the endoplasmic reticulum and the nucleus has homology to Dnad, an Escherichia coli heat shock protein. J. Cell Biol. 109, 2665-2675.

Sanger, F., Miklen, S., and Coulson, A. R. (1977). DNA sequencing with chain terminating inhibitors. Proc. Natl. Acad. Sci. USA 74, 54635467.

Scherer, P. E., Krieg, U. C., Hwang, S. T. Vestweber, D., and Schatz G. (1990). A precursor protein partly translocated into yeast mitochondria is bound to a 70 kd mitochondrial stress protein. EMBO J. 9 , $4315-4322$.

Schröder, H., Langer, T., Hartl, F.-U., and Bukau, B. (1993). DnaK, DnaJ and GrpE form a cellular chaperone machinery capable of repairing heat-induced protein damage. EMBO J. 12, 4137-4144.

Schwarz, E., Seytter, T., Guiard, B., and Neupert, W. (1993). Targeting of cytochrome $b_{2}$ into the mitochondrial intermembrane space: specific recognition of the sorting signal. EMBO J. 12, 2295-2302.

Schwarz, E., Westermann, B., Caplan, A. J., Ludwig, G., and Neupert, $W$. (1994). XDJ1, a gene encoding a novel nonessential DnaJ homolog from Saccharomyces cerevisiae. Gene, in press.

Sherman, F., Fink, G. R., and Hicks, J. (1986). Methods in Yeast Genetics: A Laboratory Course (Cold Spring Harbor, New York: Cold Spring Laboratory Press).

Sikorski, R. S., and Hieter, P. (1989). A system of shuttle vectors and yeast host strains designed for efficient manipulation of DNA in Saccharomyces cerevisiae. Genetics 122, 19-27.

Silver, P. A., and Way, J. C. (1993). Eukaryotic DnaJ homologs and the specificity of Hsp70 activity. Cell 74, 5-6.

Smith, V., Craxton, M., Bankier, A., Brown, C. M., Rawlinson, W. D. Chee, M. S., and Barrell, B. G. (1993). Microtitre methods for the preparation and fluorescent sequencing of M13 clones. Meth. Enzymol. 218, 173-187.

Southern, E. M. (1975). Detection of specific sequences among DNA fragments separated by agarose gel electrophoresis. J. Mol. Biol. 98 , 503-517.

Stueber, D., Ibrahimi, I., Cutler, D., Dobberstein, B., and Bujard, H. (1984). A novel in vitro transcription-translation system: accurate and efficient synthesis of single proteins from cloned DNA sequences. EMBO J. 3, 3143-3148.

Wickner, S., Hoskins, J., and McKenney, K. (1991). Function of DnaJ and DnaK as chaperones in origin-specific DNA binding by RepA. Nature 350, 165-167.

Young, M. R., and Craig, E. A. (1993). Saccharomyces cerevisiae HSP70 heat shock elements are functionally distinct. Mol. Cell. Biol. 13, 5637-5646.

Zhang, S., Lockshin, C., Herbert, A., Winter, E., and Rich, A. (1992). Zuotin, a putative Z-DNA binding protein in Saccharomyces cerevisiae. EMBO J. 11, 3787-3796.

Zhong, T., and Arndt, K. T. (1993). The yeast SIS1 protein, a DnaJ homolog, is required for the initiation of translation. Cell $73,1175-$ 1186.

Zylicz, M., Ang, D., Liberek, K., and Georgopoulos, C. (1989). Initiation of $\lambda$ DNA replication with purified host- and bacteriophage-encoded proteins: the role of the dnaK, dnaJ, and GrpE heat shock proteins. EMBO J. 8, 1601-1608 